\title{
Facile Green Synthetic Route to the Zinc Oxide (ZnONPs) Nanoparticles: Effect on Green Peach Aphid and Antibacterial Activity
}

\author{
Alaa Y. Ghidan ${ }^{1}$, Tawfiq M. Al-Antary ${ }^{1}$, Nidá M. Salem ${ }^{1} \&$ Akl M. Awwad ${ }^{2}$ \\ ${ }^{1}$ School of Agriculture, the University of Jordan, Amman, Jordan \\ ${ }^{2}$ Department of Materials Science, Royal Scientific Society, Amman, Jordan \\ Correspondence: Akl M. Awwad, Royal Scientific Society, Amman, Jordan. Tel: 962-6-534-4701. E-mail: \\ akl.awwad@yahoo.com; akl.awwad@rss.jo
}

Received: September 20, 2016

Accepted: October 31, 2016

Online Published: January 15, 2017

doi:10.5539/jas.v9n2p131

URL: http://dx.doi.org/10.5539/jas.v9n2p131

The research is financed by SRF, Jordan (Agr/2/13/2014).

\begin{abstract}
In this study, zinc oxide nanoparticles (ZnONPs) were synthesized using Punica granatum peel extract in onestep reaction at room temperature. Zinc oxide nanoparticles were characterized by Fourier transform infrared spectroscopy (FT-IR), X-ray diffraction (XRD), ultraviolet visible spectroscopy (UV-vis) and scanning electron microscopy (SEM). The UV-vis absorption spectrum shows an absorption band at $278 \mathrm{~nm}$ due to $\mathrm{ZnO}$ nanoparticles. XRD characterized the final product as highly crystalline $\mathrm{ZnO}$ with sizes in the range 10-40 nm. The SEM results reveal a presence of network of randomly oriented $\mathrm{ZnO}$ nanoplatelets with an average size of $40 \mathrm{~nm}$ and thicknesses of about $8 \mathrm{~nm}$. This study determined the effect of zinc oxide nanoparticles on green peach aphid and antibacterial activity.
\end{abstract}

Keywords: green synthesis, zinc oxide nanoparticles, Punica granatum peel, antibacterial activity, green peach aphid

\section{Introduction}

Zinc oxide has a potential application in sensors, solar cells, UV lasers, semiconductors, hydrogen storage devices, and catalysts. These application led many researchers to develop different routes to synthesis zinc oxide nanoparticles such as chemical route (Singh \& Gopal, 2008; Abbasi et al., 2017), hydrothermal route (Ipeksac et al., 2013; Peng et al., 2016), sol-gel template process (Kumari et al., 2010; El Ghoul et al., 2012), photoluminescence emission technique (Rocha et al., 2014), microwave-assisted hydrothermal and decomposition (Tseng et al., 2012; Mousa et al., 2013), aerosol process (Ozcelik \& Ergun, 2014), sonochemical synthesis (Zak et al., 2013), laser ablation (Thareja \& Shukla, 2007), microemulsion method (Yildırım \& Durucan, 2010), precipitation method (An et al., 2014), hydrolyzed in polar organic solvents (Ehlert et al., 2014), solid-state thermal decomposition (Soofivand et al., 2013), microwave synthesis (Sutradhar et al., 2016). These routes have many disadvantages due to difficulty of scale up the synthesis process, separation and purification of nanoparticles from surfactants, co-surfactants, organic solvents, high energy consumption, and toxic by-products. Developing green methods for synthesis ZnONPs are of importance and still a challenge for materials researchers. Recently, plant extracts have been suggested as possible eco-friendly, alternative to chemicals in synthesis of nanoparticles. Different plants extracts have been reported in the open literature for green synthesis of zinc oxide nanoparticles, such as Olea europea (Awwad et al., 2014), Eichhornia crassipes leaf (Vanathi et al., 2014), Aloe barbadensis Miller leaf (Sangeetha et al., 2011), Hibiscus subdariffa leaf (Bala et al., 2015), Solanum nigrum leaf (Ramesh et al., 2015), Camelia sinesis leaf (Shah et al., 2015), Hibiscus rosa-sinensis (Devi \& Gayathri, 2014), Cassia fistula plant extract (Suresh et al., 2015), Ocimum tenuiflorum leaves (Raut et al., 2015), Trifoliumpratense flower extract (Dobrucka \& Dugaszewska, 2016), Mimosa Pudica leaves and coffee powder (Fatimah et al., 2016), Rambutan peel extract (Karnan \& Selvakumar, 2016) Jacaranda mimosifolia flowers (Sharma et al., 2016), Terminalia chebula fruits (Rana et al., 2016) and Azadirachia indica (Madan et al., 2016). 
In this research work, we developed a green and fast route for synthesis zinc oxide nanoparticles using Punica granatum peel aqueous extract. Also this research work determined the effect of synthesized ZnONPs on green peach aphid (GPA) and antibacterial efficacy against standard strains of Gram positive Staphylococcus aureus and Gram negative Escherichia coli.

\section{Materials and Methods}

\subsection{Materials}

Zinc acetate dihydrate $\left(\mathrm{ZnC}_{4} \mathrm{H}_{6} \mathrm{O}_{2} \cdot 2 \mathrm{H}_{2} \mathrm{O}\right)$ and potassium hydroxide $(\mathrm{KOH})$ are pure grade purchased from SIGMA-Aldrich and used without further purification. Distilled water was used in all experimental work.

\subsection{Preparation of Punica granatum Peel Extract}

Fresh fruits of healthy Punica granatum were collected from local market, Amman, Jordan. Peels were washed with water to remove dust particles and then dried in shade for two weeks to remove the residual moisture. Peels aqueous extract was prepared by placing $20 \mathrm{~g}$ of dried fine powder in $500 \mathrm{ml}$ glass beaker along with $400 \mathrm{ml}$ of sterile distilled water. The mixture was boiled for $10 \mathrm{~min}$ until the color of aqueous solution changed from watery to brown. Then the mixture was cooled to room temperature and filtered with Whatman No. 1 filter paper before centrifuging at $1,200 \mathrm{rpm}$ for 5 minutes to remove biomaterials. The aqueous extract was stored at room temperature in order to be used for further experiments.

\subsection{Green Synthesis of Zinc Oxide Nanoparticles (ZnONPs)}

In a typical reaction mixture, $1.2 \mathrm{~g}$ of zinc acetate dihydrate was dissolved in $100 \mathrm{ml}$ of the distilled water in 250 $\mathrm{mL}$ conical flask and stirred magnetically at room temperature for $5 \mathrm{~min}$. Punica granatum peel aqueous extract $(\mathrm{pH} \mathrm{5)}$ was adjusted by potassium hydroxide to $\mathrm{pH}>12$. Afterwards, the alkaline peels aqueous extract was added drop wise under stirring, as soon as, the peels extract comes in contact zinc ions spontaneous change the colorless of zinc ions to yellow color. The obtained yellow mixture was left under stirring at room temperature. After one min, the yellow mixture started changing to a yellow-white suspended mixture, indicating the formation of water soluble monodispersed zinc oxide nanoparticles.

\subsection{Characterization Techniques}

Scanning electron microscopy (SEM) analysis of synthesized zinc oxide nanoparticles was done using a Hitachi S-4500 SEM machine. Powder X-ray diffraction (XRD) was performed using a X-ray diffractometer, Shimadzu, XRD-6000 with $\mathrm{CuK} \alpha$ radiation $\lambda=1.5405 \AA$ over a wide range of Bragg angles $\left(3^{\circ} \leq 2 \theta \leq 80^{\circ}\right)$. Fourier transform infrared (FT-IR) spectroscopic measurements were done using Shimadzu, IR-Prestige-21 spectrophotometer. UV-vis spectrum of zinc oxide nanoparticles was recorded, by taking $0.1 \mathrm{ml}$ of the sample and diluting it with $2 \mathrm{ml}$ deionized water, as a function of time of reaction using a Schimadzu 1601 spectrophotometer in the wave length region 200 to $700 \mathrm{~nm}$ operated at a resolution of $1 \mathrm{~nm}$.

\subsection{Green Peach Aphid}

Zinc oxide nanoparticles synthesized using aqueous Punica granatum peels was tested against the green peach aphid. Five concentrations of ZnONPs were used to find their effect on this global pest. The testing method is similar to that adopted by Ghidan et al. (2016). Two ways analysis of variance was used to compare between mortalities caused by the ZnONPs concentrations.

\subsection{Antibacterial Activity}

Zinc oxide nanoparticles synthesized using aqueous Punica granatum peel extract was tested for its potential antimicrobial activity against some selected microbes. To analyze the antimicrobial activity of the sample, the samples were subjected to Agar well Diffusion method. Diameter of the zone of inhibition was measured in mm and expressed as Mean \pm Standard Deviation.

\section{Results and Discussion}

\subsection{XRD Analysis}

The X-ray diffraction (XRD) pattern of synthesized $\mathrm{ZnO}$ nanoparticles is illustrated in Figure 1. The XRD pattern revealed the orientation and crystalline nature of zinc oxide nanoparticles. The peak position with $2 \theta$ values of $31.76^{\circ}, 34.47^{\circ}, 36.25^{\circ}, 47.54^{\circ}, 56.58^{\circ}, 62.82^{\circ}, 65.55^{\circ}, 67.94^{\circ}, 68.88^{\circ}, 72.33$, and $76.67^{\circ}$ are indexed as (100), (002), (101), (102), (110), (103), (200), (112), (201), (004), and (202) planes, which are in good agreement with those of powder $\mathrm{ZnO}$ obtained from the International Center of Diffraction Data card (JCPDS-36-1451) confirming the formation of a crystalline monoclinic structure. No extra diffraction peaks of other phases are detected, indicating the phase purity of $\mathrm{ZnO}$ nanoparticles. The average crystallite size of the 
synthesized zinc oxide nanoparticles was calculated to be $20 \mathrm{~nm}$ using Debye-Scherrer equation (Awwad et al., 2014; Raut et al., 2015).

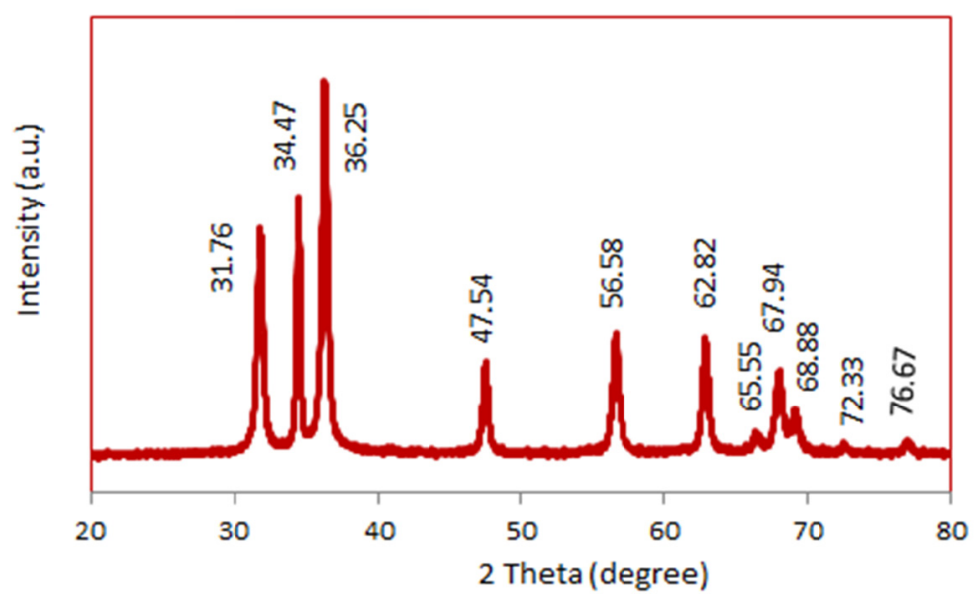

Figure 1. XRD pattern of synthesize zinc oxide nanoparticles

\subsection{FT-IR Analysis}

FT-IR Spectrum of Punica granatum peels, Figure 2 display strong and abroad absorption bands at 3518-3232 $\mathrm{cm}^{-1}$, which could be ascribed to the stretching absorption bands of amino (-NH) and hydroxyl (-OH) stretching $\mathrm{H}$ bonded alcohols and phenols. The strong absorption peak at $2928 \mathrm{~cm}^{-1}$ could be assigned to the asymmetric and symmetric stretching of $-\mathrm{CH}_{2}$ and $-\mathrm{CH}_{3}$ functional groups of aliphatic. Peak at $1728 \mathrm{~cm}^{-1}$ corresponds to stretching carboxyl groups. The band at $1616 \mathrm{~cm}^{-1}$ is characteristic of amide carbonyl group in amide I and amide II. The bands at $1520 \mathrm{~cm}^{-1}$ and $1446 \mathrm{~cm}^{-1}$ is assigned to the methylene scissoring vibrations from the proteins. C-N stretch of aromatic amines and carboxylic acids gives rise to band at $1350 \mathrm{~cm}^{-1}$. The band at 1234 $\mathrm{cm}^{-1}$ is due to $\mathrm{CO}$ vibrations of alcohols, phenols and C-N stretching vibrations of amine. The band at $1026 \mathrm{~cm}^{-1}$ assigned to the $\mathrm{C}-\mathrm{O}$ stretching vibrations of alcohols. The peaks at $879 \mathrm{~cm}^{-1}, 768 \mathrm{~cm}^{-1}$, and $509 \mathrm{~cm}^{-1} \mathrm{can} \mathrm{be}^{-1}$ assigned to aromatic compounds. These functional groups act as dispersing, capping and stabilizing agents for ZnONPs during the process of synthesis. FT-IR spectrum of the synthesized ZnONPs, Figure 3 indicated a new chemistry linkage on the surface of $\mathrm{ZnO}$ nanoparticles. This suggests that Punica granatum peel extract can bind to zinc oxide nanoparticles through carbonyl of the amino acid residues in the protein of the extract, therefore acting as stabilizer and dispersing agent for synthesized zinc oxide nanoparticles and prevent agglomeration of nanoparticles. The main characteristic peaks of Punica granatum peel extract were observed in FT-IR spectrum of zinc oxide nanoparticles; the FT-IR spectrum of the ZnO nanoparticles show strong and sharp peaks at 567 $\mathrm{cm}^{-1}$ and $440 \mathrm{~cm}^{-1}$. 


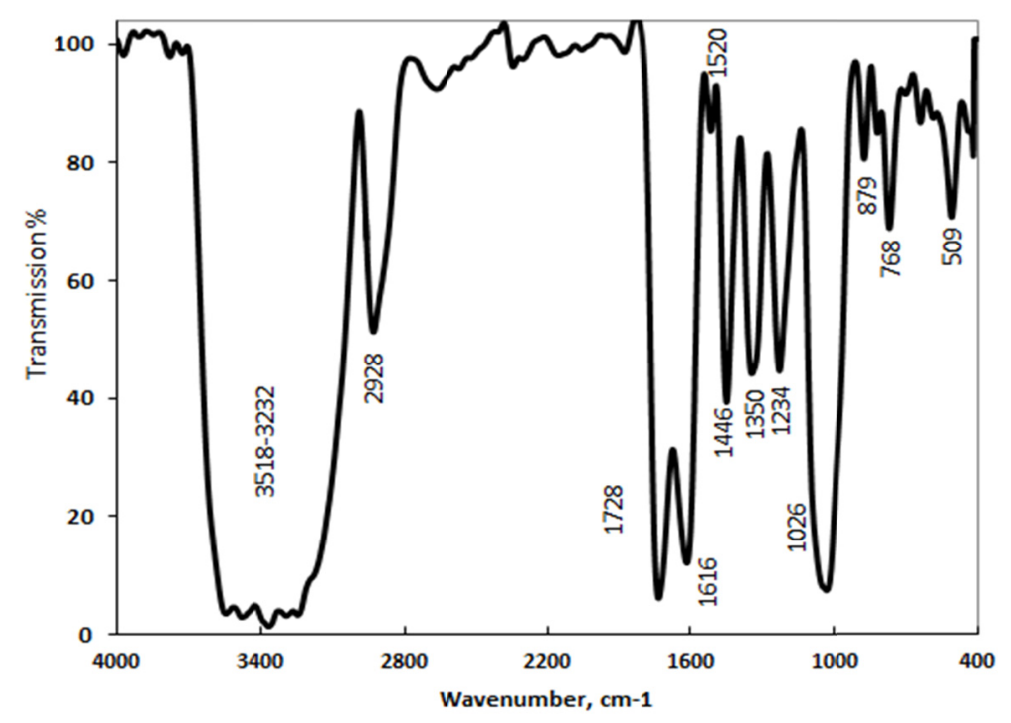

Figure 2. FT-IR spectrum of Punica granatum peel extract

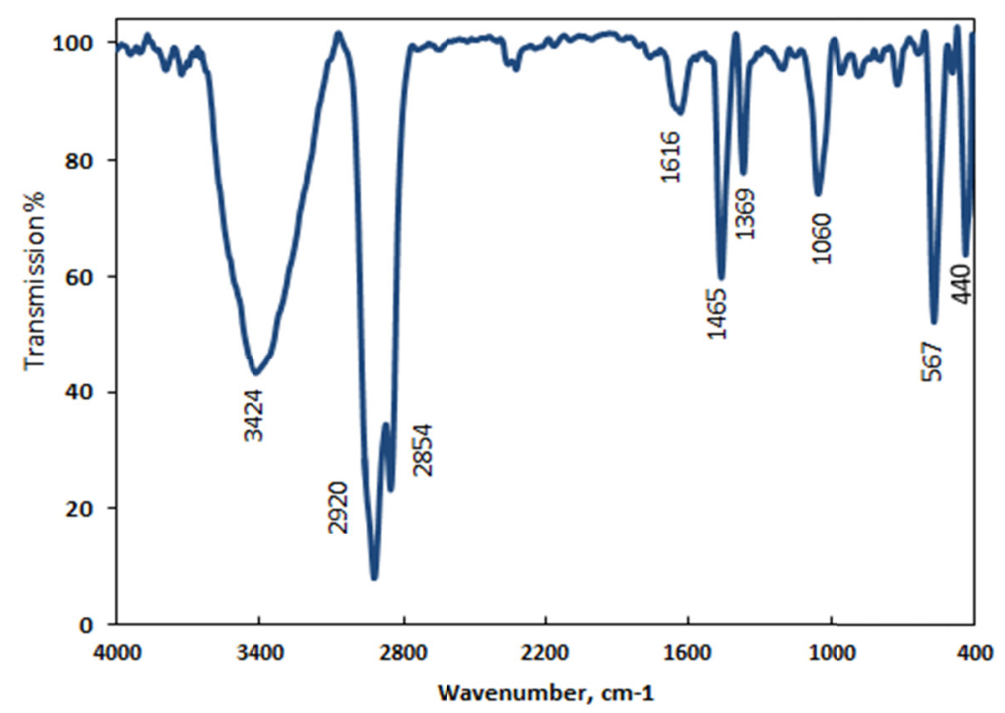

Figure 3. FT-IR spectrum of synthesized ZnONPS

\section{$3.3 U V$-vis Spectroscopy}

It is known that UV-vis spectroscopy is the most widely used technique for the structural characterization of nanoparticles. The absorbance of the $\mathrm{ZnO}$ reaction mixture was monitored in the range of 200-700 nm. Typical excitation absorption at $278 \mathrm{~nm}$ was observed at room temperature.

\subsection{SEM Images Analysis}

Scanning electron microscopy (SEM) images of synthesized zinc oxide nanoparticles by this green method are shown in Figure 4. It was found that the Punica granatum peel extract strongly influences the morphologies of the resultant zinc oxide nanoparticles. As-synthesized zinc oxide were mainly composed of Nano-flowers and Nano-platelets sizes ranges with the average size in the range of $40 \mathrm{~nm}$ and primary particles coalesced together to form larger-sized secondary particles,. While using larger quantities of Punica granatum peel extract in synthesis process, zinc oxide Nano-flowers were obtained (Figure 4A). Smaller quantities with quite surface were synthesized with an average size of ca. $40 \mathrm{~nm}$ and average thickness of $8 \mathrm{~nm}$. Figure 4B showed a quite dense morphology compromised of randomly oriented overlapping, thin sheets of ZnONPs where the individual sheets appear to have a lateral dimension of less than $300 \mathrm{~nm}$. A good estimate of the Nano-sheets thickness is in 
the range of 10 to $30 \mathrm{~nm}$. However, it is possible that the thicker sheets may consist of several thinner sheets aggregated to form Nano-platelets networks. Such ZnONPs platelet format form a useful baseline in the sense of demonstrating that $\mathrm{ZnO}$ of very high crystallinity and near-perfect stoichiometry which agrees well with the XRD results.
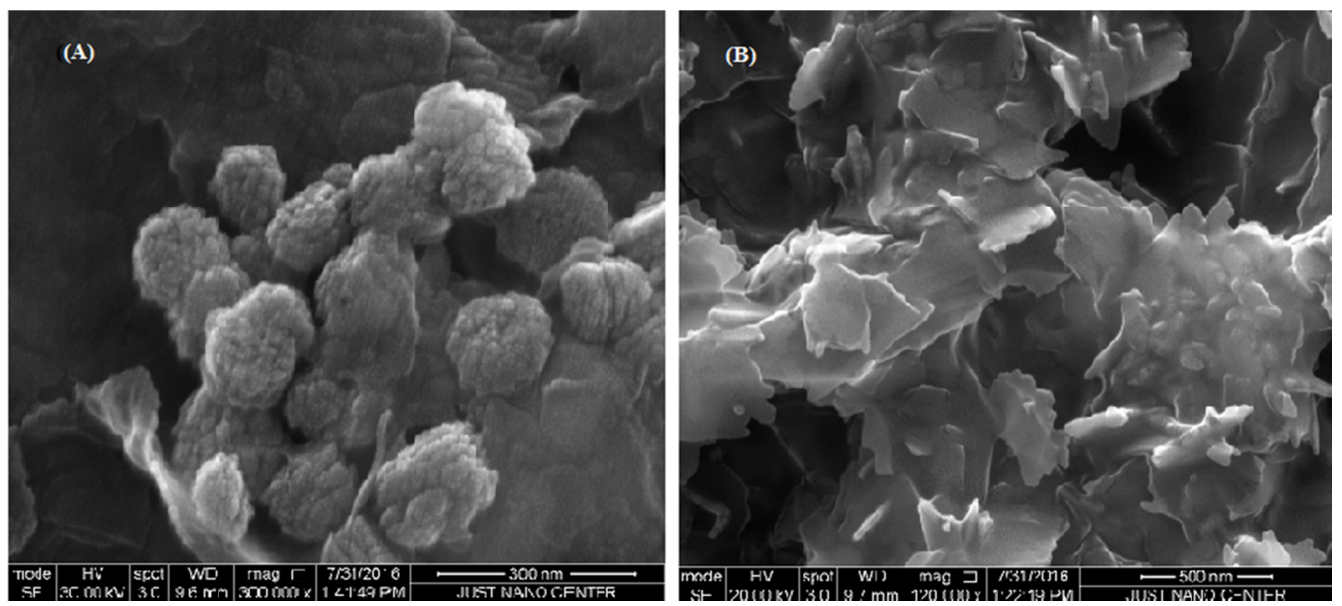

Figure 4. SEM images of synthesized ZnONPs: (A) flowers shape and (B) platelets shape

\subsection{Antibacterial Activity}

The green synthesized zinc oxide nanoparticles showed a significant antibacterial activity against Gram positive and Gram negative bacteria. The antibacterial activity results against Gram positive Staphylococcus aureus and Gram negative Escherichia coli. Chloramphenicol was used as a control antibacterial agent. Maximum zone of inhibition (MZI) are listed in Table 1. It was observed that an increase in ZnONPs concentration increases the MZI of Staphylococcus aureus and Escherichia coli. The results indicated that green synthesized zinc oxide nanoparticles showed effective antibacterial activity against $S$. aureus and E. coli. Also our results indicated that the inhibitory effect increase with an increase in the concentrations of ZnONPs.

Table 1. Antibacterial activity of ZnONPs against selected bacteria

\begin{tabular}{lll}
\hline ZnONPs $(\mu \mathrm{g} / \mathrm{L})$ & S. aureus & E. coli \\
\hline 200 & $16 \pm 0.21$ & $11.8 \pm 0.05$ \\
100 & $14 \pm 0.06$ & $10.7 \pm 0.06$ \\
50 & $12 \pm 0.07$ & $9 \pm 0.07$ \\
Reference drug & $20 \pm 2.44$ & $20 \pm 2.28$ \\
\hline
\end{tabular}

\subsection{Effect on Green Peach Aphid}

The effect of different concentrations of ZnONPs on GPA is shown in Tables 2 and 3. Means of mortality $\%$ of the $1^{\text {st }}$ and $2^{\text {nd }}$ nymphal instars caused by the five concentrations were different significantly, Table 2 . Means of mortality $\%$ of $3^{\text {rd }}$ and $4^{\text {th }}$ nymphal instars of the same aphid caused by the same concentrations were also different significantly. However, mortality \% of both aphid categories in all concentrations was greater significantly than the control treatment.

The highest mortality $\%$ of $1^{\text {st }}$ and $2^{\text {nd }}$ nymphal instars was in $8000 \mu \mathrm{g} / \mathrm{ml}$ concentration. It was $75.5 \%$ after $24 \mathrm{~h}$, then reached $100 \%$ after $48 \mathrm{~h}$ and $72 \mathrm{~h}$, while mortality increased at $4000 \mu \mathrm{g} / \mathrm{ml}$ concentration reached 90 and 100 after $48 \mathrm{~h}$ and $72 \mathrm{~h}$ respectively. The lowest mortality was in case of using $250 \mu \mathrm{g} / \mathrm{ml}$ after $24 \mathrm{~h}$ then increased to 43 and $75 \%$ after $48 \mathrm{~h}$ and $72 \mathrm{~h}$, respectively. The mortalities in case of control were significantly the least after $24 \mathrm{~h}, 48 \mathrm{~h}$ and $72 \mathrm{~h}$ compared with the other treatments.

The highest mortality $\%$ of $3^{\text {rd }}$ and $4^{\text {th }}$ nymphal instars was in $8000 \mu \mathrm{g} / \mathrm{ml}$ concentration, Table 3. It was $74.0 \%$ after $24 \mathrm{~h}$, then reached $65 \%, 100 \%$ after $48 \mathrm{~h}$ and $72 \mathrm{~h}$, respectively, while mortality increased at $4000 \mu \mathrm{g} / \mathrm{ml}$ concentration reached $55.0 \%$ after $48 \mathrm{~h}$ and $72 \mathrm{~h}$ respectively. The lowest mortality was in case of using 250 
$\mu \mathrm{g} / \mathrm{ml}$ after $24 \mathrm{~h}$ then increased to $35.0 \%$ and $58.5 \%$ after $48 \mathrm{~h}$ and $72 \mathrm{~h}$, respectively. The mortalities in case of control were significantly the least after $24 \mathrm{~h}, 48 \mathrm{~h}$ and $72 \mathrm{~h}$ compared with the other treatments.

Table 2. Means of mortality percent (\%) of $1^{\text {st }}$ and $2^{\text {nd }}$ nymphal instars of the green peach aphid by five different concentrations of ZnONPs

\begin{tabular}{llll}
\hline \multirow{2}{*}{ Concentration $(\mu \mathrm{g} / \mathrm{ml})$} & \multicolumn{3}{c}{ Mortality $\%$ of $1^{\text {st }}$ and $2^{\text {nd }}$ nymphal instars } \\
\cline { 2 - 4 } & After $24 \mathrm{~h}$ & After $48 \mathrm{~h}$ & After $72 \mathrm{~h}$ \\
\hline Control & $4.0 \mathrm{~d}$ & $5.0 \mathrm{e}$ & $5.0 \mathrm{~d}$ \\
250 & $29.5 \mathrm{c}$ & $43.0 \mathrm{~d}$ & $75.0 \mathrm{c}$ \\
1000 & $34.5 \mathrm{c}$ & $55.0 \mathrm{c}$ & $83.0 \mathrm{bc}$ \\
2000 & $60.5 \mathrm{~b}$ & $92.0 \mathrm{~b}$ & $92.0 \mathrm{ab}$ \\
4000 & $66.0 \mathrm{ab}$ & $90.0 \mathrm{~b}$ & $100 \mathrm{a}$ \\
8000 & $75.5 \mathrm{a}$ & $100 \mathrm{a}$ & $100 \mathrm{a}$ \\
\hline
\end{tabular}

Note. * Means within the same colum of the same period of time sharing the same letter do not differ significantly at $5 \%$ level using Frisher protected LSD test.

Table 3. Means of mortality percent (\%) of $3^{\text {rd }}$ and $4^{\text {th }}$ nymphal instars of the green peach aphid by five different concentrations of $\mathrm{ZnONPs}$

\begin{tabular}{llll}
\hline \multirow{2}{*}{ Concentration $(\mu \mathrm{g} / \mathrm{ml})$} & \multicolumn{3}{c}{ Mortality $\%$ of $3^{\text {rd }}$ and $4^{\text {th }}$ nymphal instars } \\
\cline { 2 - 4 } & After $24 \mathrm{~h}$ & After $48 \mathrm{~h}$ & After $72 \mathrm{~h}$ \\
\hline Control & $3.0 \mathrm{e}$ & $4.0 \mathrm{c}$ & $5.0 \mathrm{c}$ \\
250 & $17.5 \mathrm{~d}$ & $35.0 \mathrm{ab}$ & $58.5 \mathrm{~b}$ \\
1000 & $25.0 \mathrm{~d}$ & $31.0 \mathrm{ab}$ & $61.0 \mathrm{~b}$ \\
2000 & $38.0 \mathrm{c}$ & $65.0 \mathrm{a}$ & $55.0 \mathrm{~b}$ \\
4000 & $58.0 \mathrm{~b}$ & $55.0 \mathrm{a}$ & $55.0 \mathrm{~b}$ \\
8000 & $74.0 \mathrm{a}$ & $65.0 \mathrm{a}$ & $100 \mathrm{a}$ \\
\hline
\end{tabular}

Note. * Means within the same colum of the same period of time sharing the same letter do not differ significantly at 5\% level using Frisher protected LSD test.

\section{Conclusion}

In the present work, we first report an eco-friendly and simple method for the synthesis of zinc oxide nanoparticles using Punica granatum peel extract. FTIR analysis of aqueous Punica granatum peel extract indicated the presence of phyto-constituents such as amines, aldehydes, phenols, and alcohols which were the surface active molecules stabilized the zinc oxide nanoparticles. XRD analysis reveals that the average size of the nanoparticles was found to be $20 \mathrm{~nm}$ which was calculated by Debye-Scherrer equation. FT-IR and XRD results corroborated the purity of the synthesized ZnONPs. Green synthesized ZnONPs was evaluated against green peach aphid, the results showed significant effect on this aphid compared with the control treatment. Gram positive Staphylococcus aureus and Gram negative Escherichia coli showing significant effective activity. The method of the present study offers several important advantageous features. First, the synthesis route is economical and environmentally friendly, because it involves inexpensive and non-toxic materials for second, large scale synthesis.

\section{References}

Abbasi, H. Y., Habib, A., \& Tanveer, M. J. (2017). Synthesis and characterization of nanostructures of $\mathrm{ZnO}$ and $\mathrm{ZnO} /$ Graphene composites for the application in hybrid solar cells. J. Alloys and Compounds, 690, 21-26. http://dx.doi.org/10.1016/j.jallcom.2016.08.161

An, D., Li, Y., Lian, X., Zou, Y., \& Deng, D. (2014). Synthesis of porous ZnO structure for gas sensor and photocatalytic applications. Colloids and Surfaces A: Physicochem. Eng. Aspects., 447, 81-87. http://dx.doi.org/10.1016/j.colsurfa.2014.01.060 
Awwad, A. M., Albiss, B., \& Ahmad, A. L. (2014). Green Synthesis, Characterization and Optical Properties of Zinc Oxide Nanosheets Using Olea Europea Leaf Extract. Adv. Mater. Lett., 5, 520-524. http://dx.doi.org/ 10.5185/amlett.2014.5575

Bala, N., Saha, S., Chakraborty, M., Maiti, M., Das, S., Basu, R., \& Nandy, P. (2015). Green synthesis of zinc oxide nanoparticles using Hibiscus subdariffa leaf extract: effect of temperature on synthesis, anti-bacterial activity and anti-diabetic activity. RSC $A d v$., 5, 4993-5003. http://dx.doi.org/10.1039/C4RA12784F

Devi, R. S., \& Gayathri, R. (2014). Green synthesis of zinc oxide nanoparticles by using Hibiscus rosa-sinensis. Int. J. Curr. Eng. Technol., 4, 2444-2446. Retrieved from http://inprressco.com/category/ijcet

Dobrucka, R., \& Dugaszewska, J. (2016). Biosynthesis and antibacterial activity of $\mathrm{ZnO}$ nanoparticles using Trifolium pratense flower extract. Saudi J. Biolog. Sci., 23, 517-523. http://dx.doi.org/10.1016/j.sjbs.2015. 05.016

Ehlert, S., Lunkenbein, T., Breu, J., \& Förster, S. (2014). Facile large-scale synthetic route to monodisperse ZnO nanocrystals. Colloids and Surfaces A: Physicochem. Eng. Aspects, 444, 76-80. http://dx.doi.org/10.1016/ j.colsurfa.2013.12.034

El Ghoul, J., Barthou, C., \& El Mir, L. (2012). Synthesis by sol-gel process, structural and optical properties of nanoparticles of zinc oxide doped vanadium. Superlattices and Microstructures, 51, 942-951. http://dx.doi.org/10.1016/j.spmi.2012.03.013

Fatimah, I., Pradita, R. Y., \& Nurfalinda, A. (2016). Plant extract mediated of $\mathrm{ZnO}$ nanoparticles by using ethanol extract of Mimosa pudica Leaves and coffee powder. Procedia Eng., 148, 43-48. http://dx.doi.org/ 10.1016/j.proeng.2016.06.483

Ghidan, A. Y., Al-Antarya, T. M., \& Awwad, A. M. (2016). Green synthesis of copper oxide nanoparticles using Punica granatumpeels extract: Effect on green peach Aphid. Environmental Nanotechnology, Monitoring \& Management, 6, 95-98. http://dx.doi.org/10.1016/j.enmm.2016.08.002

Ipeksac, T., Kaya, F., \& Kaya, C. (2013). Hydrothermal synthesis of zinc oxide ( $\mathrm{ZnO}$ ) nanotubes and its electrophoretic deposition on nickel filter. Mater. Lett., 100, 11-14. http://dx.doi.org/10.1016/ j.matlet.2013.02.099

Karnan, T., \& Selvakumar, S. A. S. (2016). Biosynthesis of $\mathrm{ZnO}$ nanoparticles using rambutan (Nephelium lappaceum L.) peel extract and their photocatalytic activity on methyl orange dye. J. Molecular Structure, 1125, 358-365. http://dx.doi.org/10.1016/j.molstruc.2016.07.029

Kumari, L., Li, W. Z., Vannoy, C. H., Leblanc, R. M., \& Wang, D. Z. (2010). Zinc oxide micro- and nanoparticles: Synthesis, structure and optical properties. Mater. Res. Bulletin, 45, 190-196. http://dx.doi.org/10.1016/j.materresbull.2009.09.021

Madan, H. R., Sharma, S. C., Udayabhanu, Suresh, D., Vidyad, Y. S., Nagabhushanae, H., ... Maiya, P. S. (2016) Facile green fabrication of nanostructure $\mathrm{ZnO}$ plates, bullets, flower, prismatic tip, closed pine cone: Their antibacterial, antioxidant, photoluminescent and photocatalytic properties. Spectrochimica Acta Part A: Molecular and Biomolecular Spectroscopy, 152, 404-416. http://dx.doi.org/10.1016/j.saa.2015.07.067

Mousa, M. A., Bayoumy, W. A. A., \& Khairy, M. (2013). Characterization and photo-chemical applications of nano- $\mathrm{ZnO}$ prepared by wet chemical and thermal decomposition methods. Mater. Res. Bulletin, 48, 4576-4582. http://dx.doi.org/10.1016/j.materresbull.2013.07.050

Ozcelik, B. K., \& Ergun, C. (2014). Synthesis of $\mathrm{ZnO}$ nanoparticles by an aerosol process. Ceramics Inter, 40, 7107-7116. http://dx.doi.org/10.1016/j.ceramint.2013.12.044

Peng, J., Guo, W., Yang, W., Shi, C., Liu, M., Zheng, Y., ... Yuqian, Y. (2016). Synthesis of three-dimensional flower-like hierarchical $\mathrm{ZnO}$ nanostructure and its enhanced acetone gas sensing properties. J. Alloys and Compounds, 654, 371-378. http://dx.doi.org/10.1016/j.jallcom.2015.09.120

Ramesh, M., Anbuvannan, M., \& Viruthagiri, G. (2015). Green synthesis of ZnO nanoparticles using Solanum nigrum leaf extract and their antibacterial activity. Spectrochimica Acta Part A: Molecular and Biomolecular Spectroscopy, 136, Part B, 864-870. http://dx.doi.org/10.1016/j.saa.2014.09.105

Rana, N., Chand, S., \& Gathania, A. K. (2016). Green synthesis of zinc oxide nanosized spherical particles using Terminalia chebula fruits extract for their photocatalytic applications. Inter. Nano Lett., 6, 91-98. http://dx.doi.org/10.1007/s40089-015-0171-6 
Raut, S., Thorat, P. V., \& Thakre, R. (2015). Green synthesis of zinc oxide (ZnO) nanoparticles using Ocimum tenuiflorum leaves. Inter. J. Sci. and Res., 4, 1225-1228. Retrieved from http://www.ijsr.net/SUB154428

Rocha, L. S. R., Deus, R. C., Foschini, C. R., Moura, F., Gonzalez Garcia, F., \& Simões, A. Z. (2014). Photoluminescence emission at room temperature in zinc oxide nano-columns. Mater. Res. Bulletin, 50, 12-17. http://dx.doi.org/10.1016/j.materresbull.2013.09.049

Sangeetha, G., Rajeshwari, S., \& Venckatesh, R. (2011). Green synthesis of zinc oxide nanoparticles by aloe barbadensis miller leaf extract: Structure and optical properties. Mater. Res. Bulletin, 46, 2560-2566. http://dx.doi.org/10.1016/j.materresbull.2011.07.046

Shah, R. K., Boruah, F., \& Parween, N. (2015). Synthesis and Characterization of ZnO Nanoparticles using Leaf Extract of Camelia sinesis and evaluation of their antimicrobial efficacy. Int. J. Curr. Microbiol. App. Sci., 4, 444-450. Retrieved from http://www.ijcmas.com

Sharma, D., Myalowenkosi, I., Sabela, M. I., Kanchi, S., Mdluli, P. S., Singh, G., ... Bisetty, K. (2016). Biosynthesis of $\mathrm{ZnO}$ nanoparticles using Jacaranda mimosifolia flowers extract: Synergistic antibacterial activity and molecular simulated facet specific adsorption studies. J. Photochem. \& Photobiol. B: Biology, 162, 199-207. http://dx.doi.org/10.1016/j.jphotobiol.2016.06.043

Singh, S. C., \& Gopal, R. (2008). Synthesis of colloidal zinc oxide nanoparticles by pulsed laser ablation in aqueous media. Physica E, 40, 724-730. http://dx.doi.org/10.1016/j.physe.2007.08.155

Soofivand, F., Salavati-Niasari, M., \& Mohandes, F. (2013). Novel precursor assisted synthesis and characterization of zinc oxide nanoparticles/nanofibers. Mater. Lett., 98, 55-58. http://dx.doi.org/10.1016/ j.matlet.2013.01.129

Suresh, D., Nethravathi, P. C., Udayabhanu, Rajanaika, H., \& Sharma, S. C. (2015). Green synthesis of multifunctional zinc oxide $(\mathrm{ZnO})$ nanoparticles using Cassia fistula plant extract and their photodegradative, antioxidant and antibacterial activities. Mater. Sci. Semiconductor Process, 31, 446-454. http://dx.doi.org/ 10.1016/j.mssp.2014.12.023

Sutradhar, P., Debbarma, M., \& Saha, M. (2016). Microwave synthesis of zinc oxide nanoparticles using coffee powder extract and its application for solar cell, Synthesis and Reactivity in Inorganic. Metal-Organic and Nano-Metal Chemistry, 46, 1622-1627. http://dx.doi.org/10.1080/15533174.2015.1137035

Thareja, R. K., \& Shukla, S. (2007). Synthesis and characterization of zinc oxide nanoparticles by laser ablation of zinc in liquid. Appl. Surf. Sci., 253, 8889-8895. http://dx.doi.org/10.1016/j.apsusc.2007.04.088

Tseng, C.-C., Chou, Y.-H., Liu, C.-M., Liu, Y.-M., \& Ger, M.-D. (2012). Microwave assisted hydrothermal synthesis of zinc oxide particles starting from chloride precursor. Mater. Res. Bulletin., 47, 96-100. http://dx.doi.org/10.1016/j.materresbull.2011.09.027

Vanathi, P., Rajiva, P., Narendhran, S., Rajeshwari, S., Rahman, P. K. S. M., \& Venckatesh, R. (2014). Biosynthesis and characterization of phyto mediated zinc oxide nanoparticles: A green chemistry approach. Mater. Lett., 134, 13-15. http://dx.doi.org/10.1016/j.matlet.2014.07.029

Yıldırım, O. A., \& Durucan, C. (2010). Synthesis of zinc oxide nanoparticles elaborated by microemulsion method. J. Alloys and Compounds, 506, 944-949. http://dx.doi.org/10.1016/j.jallcom.2010.07.125

Zak, A. K., Majid, W. H., Wang, H. Z., Yousefi, R., Golsheikh, A. M., \& Ren, Z. F. (2013). Sonochemical synthesis of hierarchical ZnO nanostructures. Ultrasonics Sonochemistry, 20, 395-400. http://dx.doi.org/ 10.1016/j.ultsonch.2012.07.001

\section{Copyrights}

Copyright for this article is retained by the author(s), with first publication rights granted to the journal.

This is an open-access article distributed under the terms and conditions of the Creative Commons Attribution license (http://creativecommons.org/licenses/by/4.0/). 